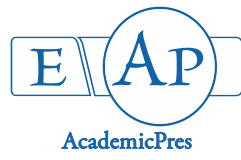

\title{
Morphologic Characteristics Variability in Prunus spinosa L. Shrubs Identified in Southern Area of Oltenia, Romania
}

\author{
Florentina GAVRILĂ CĂLUȘARU ${ }^{1}$, Sina COSMULESCU²* \\ ${ }^{1}$ University of Craiova, Horticulture Faculty, Doctoral School of Plant and Animal Resources Engineering, , A.I. Cuza Street, 13, Craiova, \\ Romania; calusaru_flory@yahoo.com \\ ${ }^{2}$ University of Craiova, Horticulture Faculty, Department of Horticulture and Food Science, A.I. Cuza Street, 13, Craiova, \\ Romania; sinacosmulescu@hotmail.com ("corresponding author)
}

\begin{abstract}
This paper aims to analyse the variability of morphological characteristics of Prunus spinosa L. shrubs, identified and studied in the spontaneous flora in southern Oltenia, Romania (localities Calopar and Gura Văii). The observations made on trunk diameter, stem height, spinosity degree, ability to form basal shoots, have outlined the high variability, which is useful in breeding programs. Variability coefficient ranged between $26.02 \%$ and $30.87 \%$ for the stem diameter, between $23.48 \%$ and $32.32 \%$ for the plant height, between $30.93 \%$ and $37.81 \%$ for canopy diameter. Based on the obtained results, the C31, GV26, GV28, GV29, GV30, GV31, GV33, GV34, GV37 and GV8, GV9, GV27, GV35, C5, C24, C25, C26 and C29 genotypes are recommended for fixing the eroded lands, owing to their very strong, strong and medium ability to form basal shoots; while C10, C12, C23, C27, C28, C30, GV6, GV10, GV24, GV25, GV32 and GV36 genotypes are recommended to be studied as rootstocks in fruit tree species, having in view the low or missing vigor and ability to form basal shoots.
\end{abstract}

Keywords: blackthorn; diversity; genotypes; selection; vigour

\section{Introduction}

Prunus spinosa $L$. is a shrub commonly found in spontaneous flora in different regions, either at lower altitudes (Parvu, 2005) up to $1000 \mathrm{~m}$ or at higher altitudes up to $2200 \mathrm{~m}$ (Özcan, 2008) in Turkey. It is more abundant in North, West and South Anatolia in the remaining forests and whole forests at altitudes between 0-1700 $\mathrm{m}$ a.s.l. (Erturk et al., 2009). Clinovschi (2005) mentions that in Romania, this species appears frequently in forest edges, woodland, on sunny hillsides, cliffs, from the plain up to the lower mountain floor $(1000 \mathrm{~m})$; it is often the subarboretum of xerothermophile oak forests (Dobrogea, Moldova) and it presents various types in the forest steppe and hilly areas (Ghena et al., 1977). It is commonly found in the spontaneous flora of southern Oltenia, in association with the hawthorn (Crataegus monogyna) and the dog rose (Rosa canina). Blackthorn is a thorny shrub with deciduous leaves, forming dense bushes with complicated branches and numerous basal shoots (Popescu and Caudullo, 2016); the fruits are small spherical drupes of about $1 \mathrm{~g}$ weight, although there are varieties (var. macrocarpa) or selections with larger fruit, some of them have even entered into culture, e.g. "buburuze" and "nemteste" fruits in Transylvania (Cociu et al., 1999; Gavrila Calusaru et al., 2017). Bakker et al. (2004) reports that P. spinosa is a clonal shrub which spreads mainly through root shoots and by clonal expansion it can form dense portions of young bush that can provide better protection against herbivores. Blackthorn is a less demanding species with regard to environment and soil conditions, is resistant to frost and drought; it loves sunny areas, is a plant searching for direct light and it does not like the shade. Being highly resistant to frost it can also be used in hilly regions. It is a xerophyte species (Cosmulescu, 2014). Netoiu et al. (2008) reports that, although blackthorn is a xerophyte (mesoxerophyte) plant, it has great adaptive amplitude, supporting well also the soils with high humidity in meadows. This study aims to emphasize the variability of morphological characteristics of Prunus spinosa L. shrubs that were identified and studied in the spontaneous flora in southern Oltenia, near villages of Calopar and Gura Vaii, in order to further use the respective genotypes according to identified characteristics, either for fixing the land subject to erosion, or for using it in fruit growing farming. 
448

\section{Materials and Methods}

\section{Biologicalmaterial}

Genotypes of Prunus spinosa L. from two populations in

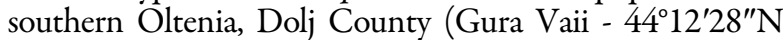

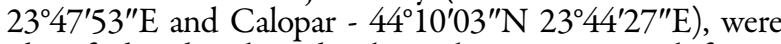
identified and evaluated. Oltenia has a continental, foreststeppe or steppe type climate, which is characterized by a thermal regime with a slight increasing trend which is caused by very high temperatures of the warm season and the rainfall regime characterized by obvious fluctuation, but with a slight decreasing trend. Thermophilic and xerothermophylous plants are suitable to this climate and they can provide pretty high crops even under the specific pluviothermal conditions of Oltenia Plain (Vladut, 2010).

Method

Growth vigor of each genotype was determined using the stem diameter and plant height characteristics (Vescan, 2011). A 1 to 5 scale of evaluation (Cociu and Oprea, 1989) was used for vigor: 1. low, 2. medium-low, 3. medium-high, 4. high, 5. very high. While the literature has not set limits on growth vigor, based on annual growth rate in Prunus spinosa L. (Asanica, 2016), the following criterion was proposed to determine the growth vigor: 1 . Low vigor at a growth rate of stem thickness between 1-3.99 mm, and at a height growth rate between $0-10 \mathrm{~cm} ; 2$. Low-to-medium vigor at a growth rate in thickness between 4-7.99 $\mathrm{mm}$ and a height growth rate between $10-20 \mathrm{~cm} ; 3$. Medium-to-high vigor at a growth rate in thickness between $8-11.99 \mathrm{~mm}$ and at a height growth rate of $20-30 \mathrm{~cm} ; 4$. High vigor, at a growth rate in thickness between $12-15.99 \mathrm{~mm}$ and a height growth rate between $30-40 \mathrm{~cm} ; 5$. Very high vigor at a growth rate in thickness between 16-19.99 mm and a height rate of more than $40 \mathrm{~cm}$.

Evaluation of trunk diameter was carried out using a caliper at $5 \mathrm{~cm}$ above the soil and expressed in millimeters, while the height was measured by means of tape measure. Canopy diameter was measured on two perpendicular directions and expressed in centimeters.

Ability of each genotype to form basal shoots was assessed based on the number of basal shoots observed in the closest proximity to mother-plant (within $50 \mathrm{~cm}$ radius range) on a 1 to 5 scale (Vescan, 2011). Further on, depending on the number of basal shoots identified, the following criterion/method was proposed to determine the ability to form basal shoots: 1. Missing ability to form basal shoots (missing basal shoots); 2. Low ability to form basal shoots (1-5 basal shoots); 3. Medium ability to form basal shoots (5-10); 4. Strong ability to form basal shoots (10-15 basal shoots); 5 . Very strong ability to form basal shoots (15-20 basal shoots).

Degree of spinosity was assessed by counting the thorns on the trunk (up to the first ramification). Depending on the number of thorns, a 1 to 5 evaluation scale was set up: 1 . Missing degree of spinosity: there is no thorn up to the first ramification; 2 . Low degree of spinosity: between 1 and 3 thorns; 3. Medium degree of spinosity: between 4 and 7 thorns; 4. Medium-to-high degree of spinosity: between 8 and 11 thorns; 5 . High degree of spinosity: between 12 and 16 thorns.

\section{Statistical analysis}

Data obtained were statistically processed, calculating the average, the standard deviation, amplitude and variation coefficient (Botu and Botu, 2010), in order to further conduct a comparison between the two populations. In order to analyze these statistical parameters the authors have used the option Data Analysis in Microsoft Office Excel program.

\section{Results and Discussion}

\section{Determination of growth vigor}

Growth vigor of shrubs was assessed based on two characteristics: trunk diameter and shrub height. The annual growth rate was calculated for each of the two characteristics, in each genotype, in order to outline the difference of growth vigor between shrubs. Data presented in Tables 1 and 2 show that among the 30 genotypes of Prunus spinosa $L$. they have a different growth vigor; the annual growth rate in thickness of genotypes in Calopar population is comprised between $2.28 \mathrm{~mm}$ and $3.48 \mathrm{~mm}$. A slightly higher difference of trunk thickness growth is noted in C10, C26, C27, C29 and C30 genotypes, with the following values of difference: $3.45 ; 2.99 ; 3.48 ; 3.27$ and 2.63 , respectively. If the annual growth rate of trunk height is analyzed, it is noteworthy that in case of genotypes of Calopar population, it has recorded values between $12 \mathrm{~cm}$ (C12) and $23 \mathrm{~cm}$ (C31). In case of Gura Vaii population (Table 2), the annual growth rate in trunk thickness is a few millimeters, ie between $1.28 \mathrm{~mm}$ (GV32) and $3.10 \mathrm{~mm}$ (in GV8 and GV33), respectively, $3.19 \mathrm{~mm}$ in GV37. In this later genotype the thickness growth rates are higher in comparison to the other genotypes within Gura Vaii population, but they are lower in comparison to certain genotypes in Calopar population. In blackthorn genotypes of Gura Vaii population the annual growth rate of shrub height has recorded values between $13 \mathrm{~cm}$ (in GV25) and $25 \mathrm{~cm}$ (in GV8). A similar difference of height growth to the value recorded in GV8 is found also in GV33 genotype $(24 \mathrm{~cm})$. In comparing the annual height growth rate of genotypes in Gura Vaii population to the genotypes in Calopar population, it is found that it has the highest values in two genotypes within Gura Vaii population (GV8 and GV33). The average growth rate in trunk thickness by population is $2.75 \mathrm{~mm}$ in case of Calopar population, and $1.95 \mathrm{~mm}$ in Gura Vaii population. The average annual growth rate of shrub height by population is $19.08 \mathrm{~cm}$ in genotypes of Calopar population and $17.78 \mathrm{~cm}$ in case of Gura Vaii population. According to the criterion set up for growth vigor that is evaluated in terms of annual growth rate, the analyzed genotypes of $P$. spinosa have low growth vigor and, respectively, low-to medium growth vigor. Results are in accordance to the ones reported by Botu (1994). As a rootstock, blackthorn is only compatible with certain European plum cultivars, whose crop volume is medium. Blackthorn is sporadically used as rootstock for plum cultivars, especially in very dry areas (Cociu et al., 1997).

Differences between genotypes of the two populations are also due to climatic and edaphic factors, having in view that genotypes belonging to Calopar population are located at an altitude between $139 \mathrm{~m}$ and $165 \mathrm{~m}$, while the ones of 
Gura Vaii population are between $81 \mathrm{~m}$ and $165 \mathrm{~m}$. The distance is $6 \mathrm{~km}$ between the two areas taken under study. The influence of climatic and edaphic factors on characteristics of fruit tree plants is also upheld by authors in other species (Cosmulescu, 2013; Botu et al., 2010; Cosmulescu and Stefănescu, 2018). Comparative statistical analysis of growth characteristics in the two populations is presented in Table 3. With regard to trunk diameter, the shrubs in Calopar population have recorded an average value of $32.32 \mathrm{~mm}$, which is higher than in genotypes of Gura Vaii population $(28.18 \mathrm{~mm})$. With regard to the average canopy diameter, the highest value was recorded in genotypes of Calopar population $(151.44 \mathrm{~cm})$, followed by the ones in Gura Vaii population $(113.74 \mathrm{~cm})$. With regard to shrub height, the variation range is found in two genotypes within the same population: $124 \mathrm{~cm}$ in GV25 and $340 \mathrm{~cm}$ in GV8 genotype (Table 2), values that are somehow in accordance with height values suggested by Woldring (2015), who considers that P. spinosa has the shape of a shrub or a small size tree, with height between 3 $\mathrm{m}$ and $5 \mathrm{~m}$. In 2018 the ranges of the same characteristic is maintained in the same genotypes: $137 \mathrm{~cm}$ (in GV25 genotype) and $365 \mathrm{~cm}$ in GV8 genotype (Table 2). Variation coefficient of trunk diameter has varied between $26.02 \%$ (in genotypes of Calopar population) and 30.87\% (in genotypes of Gura Vaii population), (Table 3), which indicates a high variability among genotypes of the same population. In terms of canopy average diameter, the variation coefficient recorded the values from $30.93 \%$ to $37.81 \%$, thus demonstrating a very high variation, and respectively, a high non-uniformity within genotypes studied. A high variation was also found in shrub height, whose variation coefficient was $32.32 \%$ in case of Gura Vaii population.

Table 1. Growth vigor of genotypes in Calopar population, expressed in terms of growth rate in thickness and height

\begin{tabular}{|c|c|c|c|c|c|c|c|}
\hline \multirow{2}{*}{ No. } & \multirow{2}{*}{ Genotype } & \multicolumn{2}{|c|}{ Trunk diameter $(\mathrm{mm})$} & \multirow{2}{*}{$\begin{array}{c}\text { Growth rate in trunk } \\
\text { diameter }(\mathrm{mm})\end{array}$} & \multicolumn{2}{|c|}{ Stem height $(\mathrm{cm})$} & \multirow{2}{*}{$\begin{array}{l}\text { Growth rate of } \\
\text { stem height }(\mathrm{cm})\end{array}$} \\
\hline & & 2017 & 2018 & & 2017 & 2018 & \\
\hline 1. & $\mathrm{C} 5$ & 33.00 & 35.41 & 2.41 & 200.00 & 217.00 & 17.00 \\
\hline 2. & $\mathrm{C} 10$ & 34.00 & 37.45 & 3.45 & 220.00 & 238.00 & 18.00 \\
\hline 3. & $\mathrm{C} 12$ & 28.88 & 31.16 & 2.28 & 220.00 & 232.00 & 12.00 \\
\hline 4. & $\mathrm{C} 23$ & 32.30 & 34.86 & 2.56 & 170.00 & 189.00 & 19.00 \\
\hline 5. & $\mathrm{C} 24$ & 25.42 & 27.98 & 2.56 & 170.00 & 191.00 & 21.00 \\
\hline 6. & $\mathrm{C} 25$ & 22.65 & 24.98 & 2.33 & 185.00 & 207.00 & 22.00 \\
\hline 7. & $\mathrm{C} 26$ & 21.11 & 24.10 & 2.99 & 150.00 & 169.00 & 19.00 \\
\hline 8. & $\mathrm{C} 27$ & 36.10 & 39.58 & 3.48 & 220.00 & 239.00 & 19.00 \\
\hline 9. & $\mathrm{C} 28$ & 22.98 & 25.58 & 2.60 & 205.00 & 225.00 & 20.00 \\
\hline 10. & $\mathrm{C} 29$ & 58.11 & 61.38 & 3.27 & 160.00 & 179.00 & 19.00 \\
\hline 11. & $\mathrm{C} 30$ & 26.65 & 29.28 & 2.63 & 310.00 & 330.00 & 20.00 \\
\hline 12. & $\mathrm{C} 31$ & 18.42 & 20.93 & 2.51 & 145.00 & 168.00 & 23.00 \\
\hline Mean & & & & $2.75 \pm 0.43$ & & & $19.08 \pm 2.77$ \\
\hline
\end{tabular}

Table 2. Growth vigor of genotypes in Gura Vaii population, expressed in terms of growth rate in thickness and height

\begin{tabular}{|c|c|c|c|c|c|c|c|}
\hline \multirow{2}{*}{ No. } & \multirow{2}{*}{ Genotype } & \multicolumn{2}{|c|}{ Trunk diameter $(\mathrm{mm})$} & \multirow{2}{*}{$\begin{array}{l}\text { Growth rate } \\
(\mathrm{mm})\end{array}$} & \multicolumn{2}{|c|}{ Stem height $(\mathrm{cm})$} & \multirow{2}{*}{ Growth rate $(\mathrm{cm})$} \\
\hline & & 2017 & 2018 & & 2017 & 2018 & \\
\hline 1. & GV6 & 45.38 & 48.17 & 2.79 & 210.00 & 218.00 & 18.00 \\
\hline 2. & GV8 & 48.55 & 51.65 & 3.10 & 340.00 & 365.00 & 25.00 \\
\hline 3. & GV9 & 21.68 & 23.84 & 2.16 & 201.00 & 216.00 & 15.00 \\
\hline 4. & GV10 & 26.52 & 27.86 & 1.34 & 226.00 & 244.00 & 18.00 \\
\hline 5. & GV24 & 21.84 & 23.18 & 1.34 & 150.00 & 166.00 & 16.00 \\
\hline 6. & GV25 & 30.99 & 32.69 & 1.70 & 124.00 & 137.00 & 13.00 \\
\hline 7. & GV26 & 38.50 & 40.16 & 1.66 & 190.00 & 208.00 & 18.00 \\
\hline 8. & GV27 & 22.38 & 23.69 & 1.31 & 175.00 & 191.00 & 16.00 \\
\hline 9. & GV28 & 27.86 & 29.16 & 1.30 & 205.00 & 223.00 & 18.00 \\
\hline 10. & GV29 & 22.99 & 25.10 & 2.11 & 153.00 & 169.00 & 16.00 \\
\hline 11. & GV30 & 20.75 & 22.11 & 1.36 & 180.00 & 197.00 & 17.00 \\
\hline 12. & GV31 & 29.56 & 30.98 & 1.42 & 200.00 & 217.00 & 17.00 \\
\hline 13. & GV32 & 18.44 & 19.72 & 1.28 & 164.00 & 180.00 & 16.00 \\
\hline 14. & GV33 & 41.90 & 45.00 & 3.10 & 330.00 & 354.00 & 24.00 \\
\hline 15. & GV34 & 22.70 & 24.96 & 2.26 & 185.00 & 200.00 & 15.00 \\
\hline 16. & GV35 & 26.41 & 27.89 & 1.48 & 212.00 & 230.00 & 18.00 \\
\hline 17. & GV36 & 51.12 & 53.29 & 2.17 & 285.00 & 306.00 & 21.00 \\
\hline 18. & GV37 & 25.26 & 28.45 & 3.19 & 230.00 & 249.00 & 19.00 \\
\hline Mean & & & & $1.95 \pm 070$ & & & $17.78 \pm 3.02$ \\
\hline
\end{tabular}


Table 3. Average, maximum and minimum values/per population of trunk and canopy diameters and shrub height

\begin{tabular}{|c|c|c|c|c|c|c|c|c|c|c|c|c|}
\hline \multirow{2}{*}{ Population } & \multicolumn{4}{|c|}{ Trunk diameter $(\mathrm{mm})$} & \multicolumn{4}{|c|}{ Canopy diameter $(\mathrm{cm})$} & \multicolumn{4}{|c|}{ Shrub height $(\mathrm{cm})$} \\
\hline & Mean \pm SD & Min. & Max. & $\mathrm{Cv} \%$ & Mean \pm SD & Min & Max & $\mathrm{C} v \%$ & Mean \pm SD & Min & Max & $\mathrm{Cv} \%$ \\
\hline Gura Vaii & $28.18 \pm 8.70$ & 17.99 & 51.12 & 30.87 & $113.74 \pm 43.01$ & 34 & 211 & 37.81 & $195.5 \pm 63.19$ & 95 & 340 & 32.32 \\
\hline Calopar & $32.32 \pm 8.41$ & 16.50 & 58.11 & 26.02 & $151.44 \pm 46.84$ & 86 & 287 & 30.93 & $217.6 \pm 51.10$ & 147 & 340 & 23.48 \\
\hline
\end{tabular}

Determination of ability to form basal shoots in each genotype

All around the analyzed genotypes one can see many basal shoots that are formed on young ramifications of roots, and they are fed until formation and development of its own roots, by the mother plant. The ability to form basal shoots was determined in each genotype, according to the method. In analyzing the data (Table 4), it results that among the 30 genotypes of $P$. spinosa, 9 genotypes have very strong and strong ability to form basal shoots (more than 10 basal shoots), 9 genotypes have medium ability to form basal shoots (6-10 basal shoots), 10 genotypes have low ability to form basal shoots (between 1 and 5 basal shoots), and only 2 genotypes (C27, C10) have not formed basal shoots (inside a circle drawn at $50 \mathrm{~cm}$ from the trunk), because of their missing ability to form basal shoots. Calculating the percentage, $30 \%$ of total number of genotypes fall within class 4 and class 5 (strong and very strong ability to form basal shoots), 30\% in class 3 (medium ability to form basal shoots), $33.33 \%$ in class 2 (low ability to form basal shoots), and only $6.66 \%$ in class 1 (missing ability to form basal shoots). It is noted that in $60 \%$ of total number of studied genotypes, the ability to form basal shoots is comprised in classes medium strong - very strong, while in $39.99 \%$ of genotypes, in classes missing - low. P. spinosa species is known for its high ability to form basal shoots (Cociu et al., 1999; Ghena et al., 2010); it is not a plant of longevity, however it is constantly renewing itself owing to its strong ability to form basal shoots (Kovács, 2016). Results obtained in terms of spinosity degree are presented in Table 5. Of the total number of 30 Prunus spinosa L. genotypes it is noted that half of genotypes have recorded a missing spinosity degree, while the other half of genotypes have recorded low degree $(6.66 \%)$, medium degree (20\%), medium-high degree (13.33\%) and high degree $(10 \%)$ of spinosity.

Table 4. Genotypes of Prunus spinosa L. selected in southern area of Oltenia for their ability to form basal shoots*

\begin{tabular}{|c|c|c|c|}
\hline No. & Genotype & Number of basal shoots & Ability to form basal shoots \\
\hline 1. & GV26 & $10-15$ & strong \\
\hline 2. & GV28 & $10-15$ & strong \\
\hline 3. & GV29 & $10-15$ & strong \\
\hline 4. & GV30 & $10-15$ & strong \\
\hline 5. & GV31 & $10-15$ & strong \\
\hline 6. & GV33 & $10-15$ & strong \\
\hline 7. & GV34 & $10-15$ & strong \\
\hline 8. & GV37 & $10-15$ & strong \\
\hline 9. & $\mathrm{C} 31$ & $15-20$ & very strong \\
\hline 10. & GV24 & $5-7$ & low \\
\hline 11. & GV25 & $5-6$ & low \\
\hline 12. & GV27 & $5-10$ & medium \\
\hline 13. & GV32 & $4-6$ & low \\
\hline 14. & GV35 & $5-8$ & medium \\
\hline 15. & GV36 & $4-6$ & low \\
\hline 16. & GV6 & $5-6$ & low \\
\hline 17. & GV8 & $6-7$ & medium \\
\hline 18. & GV9 & $5-6$ & medium \\
\hline 19. & GV10 & $1-3$ & low \\
\hline 20. & $\mathrm{C} 23$ & $2-3$ & low \\
\hline 21. & $\mathrm{C} 24$ & $7-8$ & medium \\
\hline 22. & $\mathrm{C} 25$ & $5-6$ & medium \\
\hline 23. & $\mathrm{C} 26$ & $5-6$ & medium \\
\hline 24. & $\mathrm{C} 27$ & 0 & missing \\
\hline 25. & $\mathrm{C} 28$ & $1-2$ & low \\
\hline 26. & $\mathrm{C} 29$ & $5-7$ & medium \\
\hline 27. & $\mathrm{C} 30$ & $3-4$ & low \\
\hline 28. & C 5 & $10-12$ & medium \\
\hline 29. & $\mathrm{C} 10$ & 0 & missing \\
\hline 30. & $\mathrm{C} 12$ & $3-4$ & low \\
\hline
\end{tabular}


Table 5. Degree of spinosity in Prunus spinosa L. genotypes in southern area of Oltenia

\begin{tabular}{cccc}
\hline Population & Genotype & No. of thorns & Degree of spinosity \\
\hline Gura Vaii & GV24, GV25, GV26, GV27, GV28, GV31, GV33, GV35, GV36 & 0 & Missing \\
Calopar & C23, C24, C25, C27, C28, C29 & $1-3$ & Low \\
Gura Vaii & GV9, & & Medium \\
Calopar & C31 & $4-7$ & Medium-high \\
Gura Vaii & GV32, GV37 & $8-11$ & High \\
Calopar & C10, C12, C26, C30 & peste 12 & \\
Gura Vaii & GV6, GV8, GV10, GV29 & & \\
Calopar & GV30, GV34 & C5 & \\
Gura Vaii & & & \\
Calopar & &
\end{tabular}

\section{Conclusions}

Higher diversity found in blackthorn genotypes is useful to the selection program and it indicates the fact that there is an opportunity to identify genotypes with important characteristics for farming practice. Having in view the results obtained, the authors recommend distribution of studied genotypes under the following classes, in terms of capitalization opportunities: a) In order to fixing the soils, recommended are genotypes with high ability / very high ability to form basal shoots (GV26, GV28, GV29, GV30, GV31, GV33, GV34, GV37 and C31) and medium ability (GV27, GV35, GV8, GV9, C24, C25, C26, C29, C5); b) In order to use them as rootstock in fruit tree farming, recommended are genotypes without basal shoots formation or with lower number of basal shoots: C27, C10, (without basal shoots forming) and GV24, GV25, GV32, GV36, GV6,GV10, C23, C28, C30,C12, (with lower ability to form basal shoots). Further observations shall also identify other characteristics of those genotypes to conduct a satisfactory evaluation based on capitalization guidelines.

\section{References}

Asanica A (2016). Inovații în cultura arbuştilor fructiferi. Universitatea de Științe Agronomiceși Medicină Veterinară din București.

Bakker ES, OlffH, Vandenberghe C, De Maeyer K, Smit R, Gleichman JM, Vera FWM (2004). Ecological anachronisms in the recruitment of temperate light-demanding tree species in wooded pastures. Journal of AppliedEcology 41(3):571-582.

Botu I(1994). Ameliorarea plantelor horticole. Reprografia Univ. Craiova.

Botu I, Botu M (2010). Tehnica experimentală în horticultură și ecologie (elemente de bază).Editura Conphys. Râmnicu Vâlcea pp 45-48.

Botu M, Tudor M, Botu I, Cosmulescu S, Papachatzis A (2010). Evaluation of walnut cultivars in the conditions of the Oltenia's hill area regarding functioning potential. Analele Universitatii din Craiova, seria Biologie, Horticultură, Tehnologia Prelucrării Produselor Agricole, Ingineria Mediului 15:94-103.

Clinovschi F (2005). Dendrologie. Editura Universităţii Suceava.

Cociu I, Botu I, Șerboiu L (1999). Progrese în ameliorarea plantelor horticole din România, volumul I, Pomicultură. Editura Ceres.

Cociu V, Botu I, Minoiu N, Pasc I, Modoran I (1997). Prunul. Editura Conphys.

Cociu V, Oprea S (1989). Metode de cercetare în ameliorarea plantelor pomicole. Editura Dacia, Cluj-Napoca.
CosmulescuS (2014). Pomicultură ornamentală. EdituraSitech. Craiova.

Cosmulescu S (2013). Phenotypic diversity of walnut (Juglans regia L.) in Romania - opportunity for genetic improvement. South-Western Journal of Horticulture, Biology and Environment 4:117-126.

Cosmulescu S, Stefanescu D (2018). Morphological variation among persian walnut (Juglans regia) genotypes within the population and depending on climatic year. Scientia Horticulturae 242:20-24.

Erturk Y,ErcisliS, Maghradze D, Orhan E, Agar G (2009). An assessment of genetic variability and relationships among wild-grown blackthorn (Prunus spinosa L.) plants based on RAPD markers. Genetics and Molecular Research 8(4):1238-1244.

Gavrila Calusaru F, Ionica ME, Cosmulescu SN (2017). Some fruit characteristics of blackthorn (Prunus spinosa L.). Analele Universitatii din Craiova, Seria Biologie, Horticultură, Tehnologia Prelucrării Produselor Agricole, Ingineria Mediului 22:129-136.

Ghena N, Braniște N, Stănică F (2010). Pomicultură generală. Editura Invel MultimediaS. R L. București.

Ghena N, Mihăescu Gr, Popescu M, Cireașa V, Godeanu L, Drobotă Gh (1977). Pomicultură generală și specială. Editura Didactică și Pedagogică.București.

Kovács S (2016). Specii de arbuști fructiferi în grădini și plantații comerciale. Editura Casa Oradea.

Netoiu C, Visoiu D, Badele O (2008). Dendrologie. Editura Eurobit. Timișoara.

Özcan T (2008). Some vitamin and organic acid contents in the fruits of Prunus spinosa L. subsp. dasyphylla (Schur) Domin from Europe-inTurkey.IUFS Journal ofBiology 67(2):105-114.

Parvu C (2005). Enciclopedia plantelor - plante din flora României (Vol. IV).Editura Tehnică. București.

Popescu I, Caudullo G (2016). Prunus spinosa in Europe: distribution, habitat, usage and threats. U: European atlas of forest tree species. Luxembourg. pp 145.

Vescan LA (2011). Selecția şi înmulțirea prin metode clasice şi micropropagarea unor genotipuri valoroase de cătină albă $(H$. rhamnoides ssp. carpatica) din flora spontană a României. Cluj-Napoca. Tezade doctorat.

Vladut A (2010). Ecoclimatic indexes within the Oltenia Plain. Geographical Forum 9(9):49-56.

Woldring H (2015). On the origin of plums: a study of sloe, damson, cherry plum, domestic plums and their intermediate forms. Palaeohistoria 39:535-562. 